\title{
Myxoma of Maxilla
}

M. Sikinder Hayath, Professor \& Head of Pathology, G. Rami Reddy, Professor \& Head of E.N.T., M. Janaki, Asst. Professor of Pathology. D. Kabeer, Asst. Professor of E.N.T.,

A. Seshu Prasad, Postgraduate in E.N.T., Nagesh, Postgraduate in E.N.T., C. Mohan Rao \& Purandar Pandu Rangaiah, Postgraduates in E.N.T., Government General Hospital \& Kurnool Medical College, Kurnool.

\section{Summary}

A rare case of Myxoma of right maxilla in a 25 year female, presenting as bilateral nasal obstruction with destruction of the septum and maxillary antral bone is reported.

\section{Key Words}

Myxoma. Stellate Cells.

M

yxoma is a tumour of primitive indifferent mesenchyme, closely mimiking the structure of mucoid connective tissue of unibilical cord ${ }^{3}$. Stout (1948) considered these tumours as true neoplasms 9 Myxomas may be either odontogenic affecting the tooth bearing parts of the jaw or osteogenic area. True Myxomas tend to infiltrate the surrounding structures and often recur after surgical excision ${ }^{7}$. Myxomas occur rarely in head and neck region. Radiologically demonstrable osteolytic defect can be noticed when mandible or maxilla are involved ${ }^{8}$. A case of Myxoma of left maxilla with destruction of septum and maxillary bone in a female aged 25 years is reported.

\section{Case Report}

A 25 year female attended E.N.T. out patient department with the history of left side unilateral nasal obstruction of ten months and bilateral nasal obstruction of ten days duration. The obstruction on left side is gradually increasing. There is no history of epistaxis, nasal allergy or purulant discharge from nose. Past history and menstrual history are normal.

\section{Local Examination}

Smooth reddish growth in left nostril pushing the septum towards right side and causing bilateral nasal obstruction is noticed. It is bleeding on touch. Nasopharynx, larynx and ears are normal.
Routine investigations are normal. X-ray paranasal sinuses showed space occupying lesion on left side with destruction of hard palate and left maxillary antrum. C.T. Scan revealed expansile low density mass in left nasal cavity and left maxillary anturm with no contrast enhancement (Fig. 1).

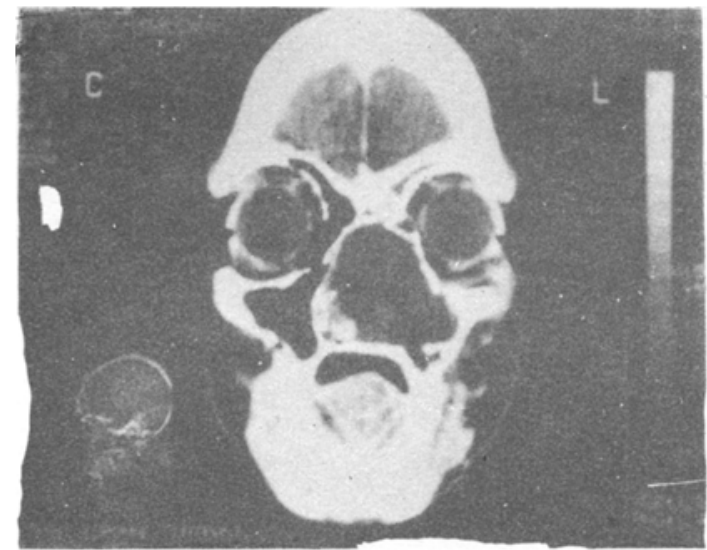

Fig. 1: C.T. Scan : Expansile low density mass in lefi nasal cavity and left Maxillary antrum with no conirast enhancement.

Under general anaesthesia caldwelluc operation is done on left side and tumour is removed in piecemeal from the maxillary antrum. Histopathology revealed sheets of characteristic stellate cells with branching cytoplasmic processes. In areas there is infiltration of tumour into the adjacent bone (Fig 2). 


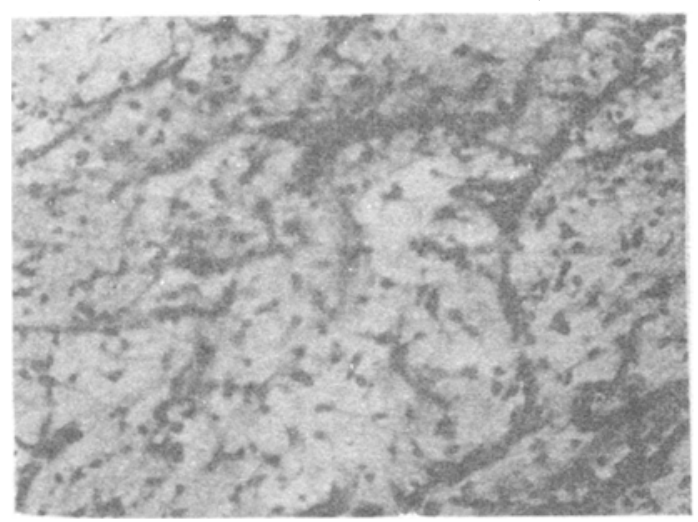

Fig. 2. Myxoma: Sheets of stellate cells with branching cytoplasmic processes. $H \& E \times 400$.

\section{Discussion}

Myxomas develop mainly in superficial soft tissues ${ }^{6}$. Myxomas of jaw have been reported by Ghosh et al in $1973^{4}$. Myxomas from the maxilla are rare and a few cases have been reported ${ }^{2,5,7,8}$. The more cellular forms are difficult to distinguish from ossifying fibroma and fibrous dysplasia'. Myxomas have to be

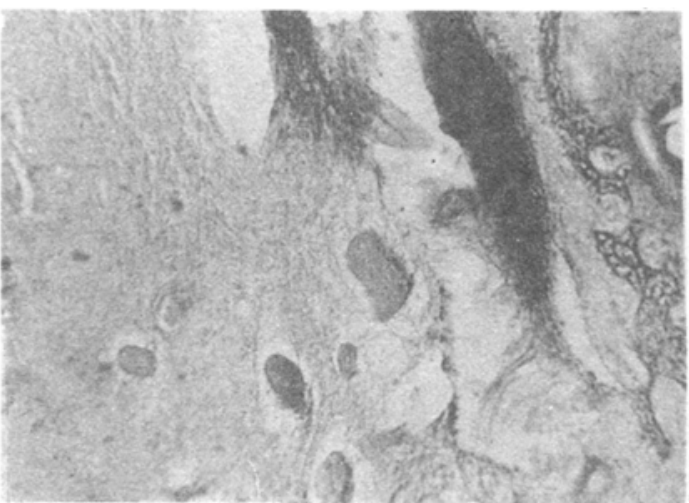

Fig. 3 Myxoma : Timour infiltration into adjacent bone. $H \& E \times 200$.

differentiated from Myxomatous degeneration, and certain malignant growths like liposarcoma, Chandrosarcoma and fibrosarcoma. These myxomas infiltrate into the surrounding tissues and often recur after surgical excision?. In the present case there is destruction of septum, hard palate and left maxillary antrum. Post operative period is uneventful and there is no evidence of recurrence of growth at present.

\section{Rererence}

1. Baluugh $G$ and Inovay J. (1972) : Recurrent Mandibular Myxoma. Report of a case. J. Oral Surg : $30: 121$.

2. Pyrd D L, Kundrick R D, Dunsworth A.R. (1973) : Myxoma of Maxilla. Report of a case. Oral Surg : $31: 123$.

3. Evan's Histological appearances of Tumours. (1978) : 3rd Edn. Edited by David J B Ashley : Chruchill Livingstone, Edingurgh, London. Page 26-27.

4. Ghosh B C, Hievos A G, Gerold F P and Miller TR (1973): Myxoma of the Jaw bones. Cancer : $31,237$.

5. Harbert F, Gary R G, Dimmette R M (1949) : Myxoma of Maxilla. Oral Surg : 2, 1414.

6. Ireland $D C R$, Soule $E H$ and Ivine $J C$ (1973): muxomas of soft tissues, Proceedings of Mayo Clinic : 48, 401 .

7. Kabir D. Banerjee C. K. And Mann S. B. S. (1985) : Fibromyxoma of Maxilla. Ind. j. Otolaryngology : $37,16$.

8. Mostafa H M, Abdellatfi S M and Martassu A M (1973) : Myxoma of Maxilla. J. Laryngol : 87, 1143.

9. Stout A P (1948) : Annals of Surgery : 127, 7067. 